\title{
TEMPORARY ACCESS TO DOCUMENTS CONTAINING MEDICAL CONFIDENTIALITY (CRIMINAL PROCEDURAL ASPECT)
}

DOI: 10.36740/WLek202005136

\author{
Serhii Ye. Ablamskyi, Vitalii V. Romaniuk, Ruslan P. Chycha, Viktoriia V. Ablamska \\ KHARKIV NATIONAL UNIVERSITY OF INTERNAL AFFAIRS, KHARKIV, UKRAINE
}

\begin{abstract}
The aim of the study: 1) to determine the features of temporary access to documents containing information that may be a medical confidentiality; 2) to identify legislative gaps regarding the regulation of the measure of criminal proceedings; 3 ) to formulate proposals for improvement of legislation in the part of the investigated issue.

Materials and methods: The legal basis for the protection of information that may be a medical confidentiality is provided. Legislative provisions have been identified and analyzed, which provide for particulars of access to documents containing information that may be a medical confidentiality. It is argued that the evidence collected in violation of the procedural order of the measure of criminal proceedings is inadmissible and therefore cannot be taken into account by the court in the future. Writing the article, the authors used both general and special methods of scientific knowledge, namely: formal-legal, formal-logical, comparative analysis and logical-normative. The complex application of these methods has made it possible to formulate science-based conclusions and proposals.

Conclusions: Exemption of documents containing information that may constitute medical confidentiality should be done exclusively by temporary access to them. In order to eliminate the legislative gaps of the investigated issue, it is proposed to amend the current legislation accordingly.
\end{abstract}

KEY WORDS: medical confidentiality, temporary access to documents, collection of evidence

1038Wiad Lek. 2020;73(5):1032-1036

\section{INTRODUCTION}

Towards becoming a democratic society in Ukraine, priority is given to developing legal guarantees for the protection of human rights and freedoms, including the protection of information that is a medical confidentiality.

According to the results of the survey of doctors of Ukraine, G.I. Reznikova identified five groups of information that $95 \%$ of respondents refer to the medical confidentiality, in particular: 1) about the disease (diagnosis, course, prognosis); 2) the medical check-up and its results; 3 ) the treatment methods used and their effectiveness; 4 ) the person who sought help (his past, relationships, physical and mental disabilities); 5) about private, family life of patients [1, p. 72-73]. As we can see, for the criminal process this issue is rather urgent, since in this sphere of the law enforcement rights, freedoms and legitimate interests of a person may be significantly restricted. In this regard, a clear procedural order for access to documents that contain medical confidentiality should be established at the legislative level.

\section{THE AIM}

The aim of this work is to determine, on the basis of the analysis of the current legislation of Ukraine, the peculiarities of temporary access to documents containing information which may be a medical confidentiality; identify gaps in the legal regulation of this measure of criminal proceedings; to formulate proposals for improvement of legislation regarding the issue under study.

\section{MATERIALS AND METHODS}

In preparing the article, the authors analyzed the normative legal acts, which stipulate the procedure for access to documents containing information that may constitute medical confidentiality. In the research process, a set of general and special methods of scientific knowledge was used to achieve this goal. In particular, formal and legal - when analyzing the provisions of the Constitution of Ukraine, criminal procedural legislation of Ukraine and other regulatory sources related to the subject of the study; formal and logical - to clarify the understanding of the conceptual and categorical apparatus related to the subject of the study; comparative analysis - when generalizing the opinions of scientists about the problems of temporary access to documents containing information that may be a medical confidentiality; logical and normative - for substantiation and formulation of amendments and additions to the current legislation of Ukraine. The complex application of these methods has made it possible to draw science-based conclusions.

\section{REVIEW AND DISCUSSION}

Nowadays, taking into account the protection of medical confidentiality in criminal proceedings, the legislator has provided for a special procedure for the storage, disclosure and use of confidential information during pre-trial proceedings and court proceedings. Both the norms of international instruments and national law are the legal 
basis for the protection of medical confidentiality. Thus, according to Art. 10 of the Convention for the Protection of Human Rights and Dignity with regard to the Application of Biology and Medicine: The Convention on Human Rights and Biomedicine, everyone has the right to respect for his or her private life with regard to information about his or her health, as well as to be acquainted with any collected information about his or her health [2].

The need to guarantee such a right is due to the fact that the physical and mental space of each person must be protected. In the interests of the patient, the state reserves the right to restrict the person in these rights in exceptional cases. As E. V. Tarasyants correctly points out, that Convention specifies and develops the provisions of the European Convention for the Protection of Human Rights and Fundamental Freedoms 1950. The 1997 Convention thus eliminates the "gaps" in the European mechanism for the protection of human rights regarding biomedical rights which are not directly protected by the 1950 Convention [3, p. 68].

At the national level, the requirements of Part 2 of Art. 32 of the Constitution of Ukraine are important, according to which it is prohibited to collect, store, use and disseminate confidential information about a person without his consent, except in cases provided for by the law, and only in the interests of national security, economic welfare and human rights [4]. It is also worth noting the provisions of Art. 39-1 in the Fundamentals of Health Legislation of Ukraine, which guarantees the patient's right to confidentiality about his state of health, the fact of seeking medical care, the diagnosis, as well as the information got during his medical check-up [5].

Due to the fact that medical confidentiality refers to the confidentiality which is protected by law, the legislator provided a special procedure for temporary access to documents containing information that may constitute medical confidentiality. In addition, in order to ensure medical confidentiality, the legislator provided for criminal liability for its unlawful disclosure. In particular, for committing the crime provided for in Art. 145 of the Criminal Code of Ukraine [6], both doctors - holders of medical confidentiality, and law enforcement officials who have become aware of that information in connection with their professional activity may be prosecuted. At the same time, neither the standards of substantive nor procedural law contain an interpretation of the concept of medical confidentiality. This, of course, prompts us to appeal to special legislation.

According to Part 1 of Art. 40 of the Law of Ukraine "Fundamentals of Health Legislation of Ukraine", medical confidentiality is information about illness, medical check-up, examination and their results, private and family aspects of life of a citizen, which became known to medical workers and other persons in connection with the performance of their professional or official duties and who have no right to disclose this information, except in cases provided for by the law. The relevant information forms the subject of medical confidentiality [5].

In the scientific literature, medical confidentiality is defined as any confidential message that contains information perceived by the sense organs or that is obvious and understandable to a person during the performance of his / her professional duties providing medical care or medical service, and which should be handled in the manner prescribed by law $[7$, p. 3], and confidentiality is defined as a social limitation for the physician and his professional duty at the same time $[8$, p. 150].

The guarantee of the medical confidentiality in the criminal process is the prohibition of interrogation of doctors and other medical workers as witnesses on information that constitutes the medical confidentiality (Part 2 of Article 65 of the Criminal Procedure Code of Ukraine) [9]. Within the relationship of civil law (Part 1 of Article 285 of the Civil Code of Ukraine), the medical documentation of an adult may be got only directly by the person concerned or by his / her representative on the basis of an order or a legal aid agreement (if the copies of that documents will be attached to the request), as well as parents (adoptive parents, guardian or caregiver) as legal representatives of a child (under 18 years) or a ward (incapacitated person) [10]. However, cases when certain medical information should be provided without the patient's consent are provided for in some health regulations. For example, according to Art. 6 of the Law of Ukraine "On Psychiatric Care" it is allowed to transfer information about the mental health of a person and provide him with psychiatric care without the consent of the person or without the consent of his legal representative. The following may occur during: 1) the provision of psychiatric care to a person suffering from a severe mental disorder; 2) conducting pre-trial or trial investigation - takes place by the written request of the investigator, prosecutor and court [11].

An analysis of the Ukrainian legislation reveals that similar but not identical concepts such as "medical confidentiality" and "medical information" exist. In this regard, the decision of the Constitutional Court of Ukraine of 30 November 1997 stated that medical confidentiality is information about the patient, and medical information is information for the patient (evidence of human health, medical history, the purpose of the proposed studies and medical measures, prognosis of possible development of the disease, including the risk to the life and health) [12]. Therefore, the subject of medical confidentiality contains information about: documented disease; medical check-up; examination and its results; private and family aspects of a citizen's life. Accordingly, medical information by its legal regime is confidential, that is, information with restricted access. In fact, information that may constitute medical confidentiality is part of medical information, the illegal disclosure of which can cause serious consequences for a person (patient) in the form of moral and / or material harm [13, p. 454]. In addition, disclosure of medical confidentiality during the pre-trial investigation can lead to negative consequences. For example, it could be in a possible counteraction to the investigation of the persons concerned, undue influence on the victims and witnesses, concealment and destruction of traces of crime, evasion of the investigation of persons involved in the crime, providing deliberately false information, etc. [14, p. 3]. 
Experience shows, reporting to the investigator, prosecutor or court information that may be medical confidentiality is often critical to the full, comprehensive and impartial investigation of killings, rapes, infectious diseases, and performing other tasks of criminal justice.

If during the pre-trial investigation there is a need to study documents that may constitute medical confidentiality, the parties to the criminal proceedings have the right to apply to the investigating judge for temporary access to information held by another person.

In accordance with the requirements of Part 6 of Art. 163 of the CPC of Ukraine permission for temporary access to documents containing the protected by law confidentiality can be given by the investigating judge only if there are two circumstances. In particular, the requesting criminal party should: 1) prove that it is possible to use the information contained in the documents as evidence; 2) impossibility to establish in other ways the circumstances, which are supposed to be proved by means of these documents. At the same time, it should be noted that according to the current legislation of Ukraine, a health care institution has the right at the request of a court to provide a certificate on attending consultations of doctors, as well as any other medical documentation that the court will need. In all other cases, including at the request of a lawyer, if, of course, the lawyer is not a representative of the requested person, the health care institution is not only entitled but also obliged to refuse to provide relevant information and / or documents.

As T. O. Kuzubova and O. O. Yukhno noted, even a mandatory certificate on the mental and drug state of a suspect's health should be obtained through temporary access to documents. Considering the above, we support the view of scientists on the need to provide in the CPC of Ukraine the right of the prosecution to obtain certificates on the stay of the suspect (accused) on the record of a psychiatrist, medical experts on drug abuse and his diagnosis based on the request (enquiry) of the investigator or prosecutor [15, p. 68-69]. The appropriateness of such changes is confirmed by the fact that, in the jurisprudence, there are a lot of cases when the evidence might be deemed admissible because of the fact that it's adduce to proceedings should be provided through temporary access to the documents, rather than by recovery or obtaining a relevant document. The root cause of this, in our view, is the ambiguous legislative interpretation and delineation of these methods of gathering evidence. Lawyers also have different views on their legal nature. Thus, S. O. Kovalchuk believes that the discovery of things can be carried out only during the temporary access to things and documents as a measure of ensuring criminal proceedings [16, p. 142], and I. M. Chemerys emphasizes that the only legal possibility to obtain documents or information about facts is only temporary access to things and documents and search [17, p. 342]. We cannot agree with the above opinions, because, despite their certain affinity, the recovery, obtaining and temporary access to things and documents still have different legal nature as ways of gathering evidence. If we accept these scientific opinions, the question is: what is the use of identifying legislatively these methods of collecting evidence separately?

Thus, a clear understanding and proper delineation of these methods of gathering evidence is of great practical importance, which, as V.V. Vapniarchuk rightly points out, is related to: a) voluntary provision by the owner; b) there is no reason to believe that the owner of the things and documents will attempt to change or destroy the relevant things or documents after receipt of the request; c) lack of protected by law confidentiality in the things and documents [18, p. 246-247]. Therefore, the scientist identified the necessary conditions under which it is possible and appropriate to use this method of gathering evidence as the recovery. Otherwise, in the absence of one of the above conditions, things and documents should be seized through temporary access to things and documents.

When applying for temporary access to documents, the recommendations of the High Specialized Court of Ukraine For Civil and Criminal Cases should be taken into account. Thus, the Letter dated 7 February 2014 stated that in considering applications for temporary access to things and documents, it should be taken into account that the use by the party of criminal proceedings such a method of gathering evidence as the seizure of documents (Part 1, Article 86, Parts 2, 3 Article 93, Part 7, Article 163 of the CPC of Ukraine) when getting access to them can be done in cases if this seizure is necessary to achieve the purpose of application of this measure of criminal proceedings [19].

The urgency of this issue is added by the fact that in Ukraine since March 1, 2019, a gradual introduction of electronic medical card has been started [20], which, in turn, in case of necessity to study information that may be a medical confidentiality, does not allow its seizure on the basis of paragraph 2, Part 1, Article 159 of the CPC of Ukraine. In such circumstances, the legislator requires to act in the manner specified in Art. 167 of the CPC of Ukraine.

A systematic analysis of the current criminal procedural legislation reveals that some of its provisions are not sufficiently worded. Moreover, certain issues of regulation of temporary access to documents containing medical confidentiality the legislator ignored. In particular, it concerns such aspects as: the term of the received documents in the possession of the investigator, the prosecutor; further procedural actions with them, etc. Of course, if the information obtained does not contain evidentiary weight, it must be returned to the rightful owner.

The analysis of court decisions reveals that, when applying to an investigating judge for permission for temporary access to documents containing medical confidentiality, individual investigators indicate the period during which they need such documents. For example, from the order of the investigating judge of the Kaluga District Court of Ivano-Frankivsk region of 26 March 2019, we see that the investigator asks for a temporary access to documents containing medical confidentiality for a month. However, in the resolution part of that order, the investigating judge did not reflect this, but only indicated the duration of the order [21]. Such an example reflects the existence in law enforcement 
of law enforcement agencies of some problematic issues and attempts to solve them through procedural decision.

If the investigator, the prosecutor intends to use as evidence the document containing information that may constitute medical confidentiality, it is advisable to arrest him. Of course, this should be done through obtaining the order of the investigating judge to ensure the preservation of material evidence (paragraph 1, Part 2, Article 170 of the CPC of Ukraine). Otherwise, at any moment there may be a situation when, for example, the holder of the document will appeal to the investigator, the prosecutor to return it. However, if the document is not properly added to the materials of criminal proceedings (in particular as evidence), it must be returned to the rightful owner.

The next aspect is related to the compliance with the requirements of Article 290 of the CPC of Ukraine by the investigator or the prosecutor, namely by granting access and being able to copy or display any material evidence or parts, documents or their copies. In this part, the problem is in the inconsistency of the provisions of criminal procedural and medical legislation. In our view, the written warning of the participants of the criminal proceedings about the inadmissibility of disclosure of the information of the pre-trial investigation is quite correct. In accordance with the provisions of Article 222 of the CPC of Ukraine disclosure of such information is possible only with the written permission of the investigator or prosecutor, and only to the extent that they deem it necessary. However, on September 27, 2009, the Code of Ethics for Physicians of Ukraine was signed by the All-Ukrainian Congress of Medical Organizations and the X Congress of the AllUkrainian Medical Society. Paragraph 3.6 of this document states that medical information about a patient may be disclosed: a) in the case of the written consent of the patient; b) in the case of a reasoned request from the bodies of inquiry, investigation, prosecutor's office and court, sanitary and epidemiological service; c) if confidentiality is a major threat to the health and life of patients and / or other persons (dangerous infectious diseases); d) in case of involvement in the treatment of other specialists for whom this information is professionally necessary [22]. Thus, such provisions of the Code of Ethics for Physicians do not fully comply with the above legal requirement on the disclosure of the medical confidentiality without the consent of the patient or his legal representative.

\section{CONCLUSIONS}

The study reveals the necessity to eliminate the legislative gap and to improve the provisions of the CPC of Ukraine regarding temporary access to documents containing medical confidentiality. Legislation on possible precautions against further misuse of documents containing medical confidentiality should also be reviewed and strengthened.

Among other things, a procedural form of recovery and receiving things and documents is advisable to consolidate in the CPC of Ukraine. Therefore there is a need, in our opinion, to amend and complement Article 93 of the CPC. In particular, it is necessary to: 1) provide that the recovery of things and documents should be made on the basis of a request, which must indicate individual or generic features of the things and documents being recovered; 2 ) to set a term within which the investigator, the prosecutor must be provided with the things or documents or their copies certified in the manner prescribed by law; 3) to provide that in the case of voluntary provision of a thing or a document which are important criminal proceedings, the investigator, the prosecutor shall prepare a record about it, and in case if the voluntary provision of a thing or document occurs during the investigative activity - in the record of such activities (for example, record on the examination of the crime scene, record of the interrogation, etc.).

\section{REFERENCES}

1. Reznikova G.I. Cryminalistychna kharacterystyka zlochyniv shchodo rozgoloshennya profesiinykh taemnyts [Forensic characteristics of crimes for disclosure of professional secrets]: dissirtation of the Candidate of Juridical sciences. Kharkiv, 2015. 264. (UA)

2. Konventsiya 0 zaschite prav i dostoinstva cheloveka v svyazi s primeneniem dostizheniy biologii i meditsinyi: Konventsiya o pravah cheloveka i biomeditsine (Oviedo, 4 April 1997) [The Convention for the Protection of Human Rights and Dignity of the Human Being with regard to Application of Biology and Medicine: Convention on Human Rights and Biomedicine]. Available from: https://zakon.rada.gov.ua/ laws/show/994_334. (UA)

3. Tarasyants E.V. Mezhdunarodno-pravovue aspekty zashchity prav cheloveka pri provedenii biomeditsynskih issledovanii [International Law Aspects of the Protection of Human Rights during Biomedical Research]. Moscow Journal of International Law. 2008; 2 (70): 62-81. (Ru)

4. Constitution of Ukraine: Law of Ukraine of 28 June. 1996 №254k / 96-BP. Available from: http://zakon.rada.gov.ua/laws/show/254k/96-ver.

5. Fundamentals of Legislation of Ukraine on Health Care: Law of Ukraine of 19.11.1992 № 2801-XII. Available from: https://zakon.rada.gov.ua/ laws/show/2801-12

6. Criminal Code of Ukraine: Law of Ukraine dated 05.04.2001 № 2341-III. Available from: https://zakon.rada.gov.ua/laws/show/2341-14.

7. Chaban 0.A. Pravo osoby na taemnytsiy pro stan zdorovia v Ukraini [Right to the health data secrecy in Ukraine]: dissertation of candidate of legal sciences (Doctor of Philosophy in Law), specialization 12.00 .03 «Civil law and civil procedure; family law; International Private law». Kyiv, 2018; 222. (UA)

8. Rieder P., Louis-Courvoisier M., Huber P. The End of Medical Confidentiality? Patients, Physicians and the State in History. Medical Humanities. 2016; 42: 149-154.

9. Criminal Procedure Code of Ukraine: Law of Ukraine of April 13, $2012 \mathrm{No}$. 4651-VI. Available from: https://zakon.rada.gov.ua/laws/show/4651-17.

10. Civil Code of Ukraine dated January 16, 2003, №. 435-IV. Available from: https://zakon.rada.gov.ua/laws/show/435-15/

11. On Psychiatric Care: Law of Ukraine of February 22, 2000 No. 1489-III. Available from: https://zakon.rada.gov.ua/laws/show/1489-14.

12. Judgment of the Constitutional Court of Ukraine considering the case of the official interpretation of Articles 3, 23, 31, 47, 48 of the Law of Ukraine "On Information" and Article 12 of the Law of Ukraine "On the Prosecutor's Office" (Case of K.G. Ustimenko) No. 5-zp / 1997 from 30.10.1997. Available from: http://zakon4.rada.gov.ua/laws/show/ v005p710-97. 
13. Slipchenko V.I. Mezhi zastosuvannya organamy dosudovogo rozsliduvannya tymchasovoho dostupu do rechei ta dokumentiv, yaki mistyat likarsku ta notarialny taemnytsu, a takozh znahodyatsya u volodinni zasobiv masovoi informatsii [The limits of the application by the pre-trial investigation authorities of temporary access to things and documents containing medical and notarial confidentiality, as well as being in the possession of the media]. Scientific Bulletin of Dnipropetrovsk State University of Internal Affairs. 2013; 3: 450-458. (UA)

14. Udalova L.D. Medychna taemnytsya u kryminalnomu protsesi Ukrainu [Medical confidentiality in the criminal process of Ukraine]. Monograph. K. 2015; 134. (UA)

15. Kuzubova T.0., Yukhno 0.A. Tymchasovyi dustup do rechei ta dokumentiv: teoretychni ta prykladni problemy [Temporary access to things and documents: theoretical and applied problems]: monograph. Edited by Doctor of Juridical Sciences, Professor 0.0. Yukhno. Kharkiv: Panov. 2019: 348. (UA)

16. Kovalchuk S.0. Vytrebuvannya ta otrymannya rechei yak sposib zbyrannya rechovyh dokaziv storonoj obvynuvachennya: teoretychni kontseptsii, normatyvne zakriplennya ta praktychne zastosuvannya [Recovery and receiving things as a way of collecting material evidence by the prosecution: theoretical concepts, regulatory support and practical application]. Scientific Bulletin of Kherson State University. 2014; 5 (3): 140-145. (UA)

17. Chemerys I.M. Problemni pytannya zbyrannya dokaziv u kryminalnomu provadzhenni [Problems of collecting evidence in criminal proceedings]. Comparative-analytical law. 2017; 5: 341-343. (UA)

18. Vapniarchuk V.V. Teoretychni osnovy kryminalnoho protsesualnoho dokazuvannya [Theoretical foundations of criminal procedural proof]: dissertation of the Doctor of Juridical Sciences. Kharkiv, 2018. 524. (UA)

19. The Higher Specialized Court of Ukraine for Civil and Criminal Cases. Generalization of case law on the consideration by the investigating judge of applications for the use of measures of criminal proceedings of 07.02.2014. Available from: https://zakon.rada.gov.ua/laws/show/ n0001740-14.

20. How and when the electronic medical card will start working in Ukraine. Official site of the Ministry of Health of Ukraine. Available from: https://moz.gov.ua/article/reform-plan/jak-i-koli-pochne-pracjuvatielektronna-medichna-kartka-v-ukraini.

21. Decision of the Kaluga District Court of Ivano-Frankivsk Region of 26.03.2019 in Case No. 1-ks / 345/490/2019. Available from: http:// www.reyestr.court.gov.ua/Review/80694639.
22. The Code of Ethics for Physicians of Ukraine of 27.09.2009. Available at: https://zakon.rada.gov.ua/rada/show/n0001748-09.

The article was performed in framework of complex research theme of Kharkiv National University of Internal Affairs «Scientific support of criminal justice system reform in Ukraine» (№ 0113U008190).

\section{Funding}

The study was financed by Kharkiv National University of Internal Affairs.

\section{ORCID and contributionships:}

Serhii Ye. Ablamskyi - 0000-0003-4716-3985 A,D,E,F

Vitalii V. Romaniuk - 0000-0001-6077-4591 A,D,E

Ruslan P. Chycha - 0000-0003-3267-2840 B,D

Viktoriia V. Ablamska - 0000-0002-2415-7235 B,F

\section{Conflict of interest:}

The Authors declare no conflict of interest.

\section{CORRESPONDING AUTHOR}

\section{Serhii Ye. Ablamskyi}

Department of Criminal Procedure and

Organization of Pre-Trial Investigation, Faculty № 1,

Kharkiv National University of Internal Affairs

L. Landau avenue, 27, 61080, Kharkiv, Ukraine

tel: +380668221377

e-mail:ablamu4@gmail.com

Received: 27.01 .2020

Accepted: 02.04 .2020

A - Work concept and design, B - Data collection and analysis, C - Responsibility for statistical analysis, D-Writing the article, $\mathbf{E}$-Critical review, $\mathbf{F}$ - Final approval of the article 